\title{
"Sintoniza el sonido, agudiza tus sentidos": una aproximación a los videoclips de Los Prisioneros
}

\author{
Javier Osorio Fernández¹, Nayive Ananías Gómez²
}

${ }^{1}$ Magíster en Estudios Latinoamericanos, Universidad de Chile. Dr. en Historia, Pontificia Universidad Católica de Chile. Docente desde 2007 en la Facultad de Filosofía y Humanidades de la Universidad Alberto Hurtado, donde ha impartido cursos de teoría e historia de la cultura en Chile y América Latina. Es profesor del Magíster en Musicología Latinoamericana de la misma universidad. Se desempeña en las áreas de la historia de la música en la modernidad latinoamericana del siglo $X X, y$ en el campo interdisciplinario de los estudios sonoros referidos a las relaciones entre arte, tecnología y sonido. Actualmente, se encuentra desarrollando una investigación sobre mediación tecnológica y reproducción sonora en Chile en la primera mitad del siglo XX. e-mail: josoriof@gmail.com

${ }^{2}$ Periodista y Magíster en Musicología Latinoamericana de la Universidad Alberto Hurtado. Ha trabajado en diversos medios de comunicación, en tres catastros de discos chilenos desarrollados por MusicaPopular.cl y en CantosCautivos.cl, proyecto creado por el Museo de la Memoria y los Derechos Humanos. Actualmente, colabora en el Programa de Investigación de Medios de la Escuela de Periodismo de la Universidad Alberto Hurtado, en el Archivo de Música de la Biblioteca Nacional de Chile y en el Répertoire International de Littérature Musicale 


\section{Resumo}

Este trabalho aborda o fenômeno do videoclipe, intentando decifrar a relação entre o visual e o som na música popular. Tomando como exemplo quatro vídeos da banda chilena Los Prisioneros pioneira na realização dessas obras audiovisuais-, nós propomos um modelo de análise que compreende duas dimensões: lugares e espaços, e o "audiologovisual" e a performance dos instrumentos. A escolha destas categorias é baseada na interdependência de conteúdo musical e referências visuais. No caso dos Prisioneros, muitas vezes as imagens reforçam os sentidos expressos nas letras, com alusões claras ao contexto sociocultural do país durante os anos 80 . Enquanto os planos e ângulos de câmara, os sons e a música reforçam os sentimentos evocados pela melodia das canções. Nos vídeos revisados, estes elementos geram no espectador uma estimulação constante, como um imperativo para mobilizar e reagir. Finalmente, nós reflexionamos sobre outras áreas possíveis de análise para tais estudos.

Palavras-chave: Videoclipe; Los Prisioneros; Análise audiovisual.

\section{Abstract}

This paper discusses the music video phenomenon, attempting to decipher the relationship between the visual and the sound in popular music. Taking as examples four videos of the Chilean band Los Prisioneros - pioneer in achieving these audiovisual works -, we propose an analysis model that considers two dimensions: places and spaces, and the "audiologovisual" and the performance of the musical instruments. The choice of these categories is based on the interdependence of musical content and visual models. In the music videos of Los Prisioneros, the images often reinforce the senses expressed in the lyrics, with clear allusions to the sociocultural context of Chile in the $80 \mathrm{~s}$. While the film shots and camera angles, sounds and music enhance the feelings evoked by the melody of the songs. In the revised music videos, these elements generate in the spectator a constant stimulation, as an imperative to mobilize and react. Finally, we reflect on other possible areas of analysis for such studies.

Keywords: Music video; Los Prisioneros; Audiovisual analysis. 


\section{Introducción}

La canción pop, como argumentan Connell y Gibson, establece una identificación y un "diálogo emocional" entre consumidores e intérpretes, según el cual se definen los sentidos y significados de la música en la experiencia de sus auditores. Por su parte, Vernallis señala, basándose en los planteamientos de Cook, que la canción en un contexto audiovisual está circundada normalmente por un "halo de recuerdos" (VERNALLIS, 2013: 228), sobre los cuales se construyen los significados culturales de una experiencia musical afectiva y emocional. El vestuario y la performance, en tanto imágenes dispuestas en el relato del video musical, podrían estrechar el vínculo de una comunidad con la música, asociando a ella ciertos materiales visuales y culturales (incluso materiales provenientes de otros textos mediatizados) que configuran la naturaleza emocional del diálogo entre intérpretes y públicos. La imagen, a su vez, podría exteriorizar estereotipos o asociaciones a ciertos lugares y estratos (CONNELL y GIBSON, 2001). Por esto, resulta interesante profundizar en el modo en que los sonidos y las imágenes -elementos predominantes en el videoclip, incluso por sobre el texto de la canción - remiten a rasgos individuales y colectivos, o aluden a localidades y grupos socioeconómicos que son vistos y escuchados en el contexto evocativo del videoclip.

El video musical - fenómeno indiscutidamente expandido a partir de la década de 1980 gracias al surgimiento del canal estadounidense MTV ${ }^{3}$ - forma parte de un universo estético y musical, en el que la audiovisualidad recompone la experiencia de la escucha y el disfrute de la música pop. De acuerdo a Chion, el sonido otorgaría a la imagen en el contexto audiovisual un "valor sensorial, informativo, semántico, narrativo, estructural o expresivo" (CHION, 1999: 278). EI video musical, especificamente, tiende, en este contexto, a construir de múltiples formas una trama donde el uso de las imágenes se hilvana de formas creativas a

\footnotetext{
${ }^{3}$ Aufderheide indica: "Cuando MTV (Music Television) se puso en marcha en 1981, su éxito fue casi instantáneo: se convirtió en la noticia del momento y reportó un aumento en las ventas de las compañías discográficas en cuestión de meses” (AUFDERHEIDE, 1986: 60).
} 
partir de su diálogo con la forma musical, siendo de este modo más abstracto, episódico o dependiente de un contexto que otros modos narrativos del cine clásico o que géneros de la visualidad popular. En cuanto a lo estilístico, el video musical puede experimentar, debido a su particular forma de relacionar imágenes y sonidos con "representaciones inusuales del tiempo, el espacio y la causalidad; enfatizar en la textura, el color y el estado de ánimo; y resaltar lo efímero" (VERNALLIS, 2013: 36), aspectos asociados por Vernallis a las técnicas de "intensificación" audiovisual, que lo inscriben en el marco de una estética contemporánea. Los videoclips, por consiguiente, originan o robustecen los lazos entre música y experiencia, a partir del modo en que las imágenes son elaboradas en el ámbito específico de funcionamiento de la canción.

Las piezas audiovisuales de la banda chilena Los Prisioneros - quienes impulsaron el desarrollo de videos realizados por jóvenes cineastas en los años ochenta (LIÑERO, 2010) - , permiten revisar estos diálogos entre música e imagen, en la elaboración de una experiencia musical e histórica de una juventud que debió enfrentarse no sólo a la destitución de un pasado musical debido a la dictadura, sino también a la recomposición, mediante el uso de las imágenes y los sonidos, de un paisaje cultural situado bajo la trama del neoliberalismo.

Los Prisioneros -grupo musical integrado por Jorge González (1964; voz, bajo), Claudio Narea (1965; guitarra) y Miguel Tapia (1964; batería) - podrían situarse en lo que García (2013) describe como canción social, pero con grandes diferencias del Canto Nuevo, en cuanto a sonoridad y propuesta estética. El Canto Nuevo, heredero en algún sentido de la Nueva Canción Chilena de los años sesenta- "se articuló en torno a una generación joven de cantores y conjuntos, muchos de ellos surgidos en facultades universitarias, que se iniciaron en peñas, parroquias y actos solidarios desde 1974 en adelante" ${ }^{4}$, quienes buscaban restablecer el sentido de una memoria fracturada debido a la presencia de la dictadura (OSORIO, 2011). En cambio, a comienzos de los '80, el Nuevo Pop Chileno se inspiró en una recepción del new wave y de la escena musical

\footnotetext{
${ }^{4}$ Recuperado de http://www.musicapopular.cl/generos/canto-nuevo/page/2/ [03/2016].
} 
británica, a partir de los cuales se construyeron los nuevos significados del pop y de la música popular en la experiencia mediatizada y sobre todo televisiva de la sociedad chilena (CONTARDO y GARCÍA, 2005).

Si bien Los Prisioneros exploraron el espacio del new wave, sin distinguirse musicalmente de otros grupos locales, sí sobresalieron por sus letras transgresoras, que interpelaron a una sociedad bajo la dictadura de Augusto Pinochet. Es por esto que este trío no sólo es objeto de estudio por su propuesta estética, sino que también por cómo sus temas repercutieron en lo emocional, generando identificación y empatía. De este modo, Los Prisioneros alcanzaron el pedestal canónico de lo que García llama "canción comprometida" (2013). Siguiendo la ruta de Violeta Parra y Víctor Jara, esta banda, al decir de Vilches, "continúa un diálogo abierto con los chilenos, al referirse a la contingencia sociopolítica actual que concierne no sólo a un país, sino que también a toda Latinoamérica" (VILCHES, 2004: 197). Los temas de Los Prisioneros reflejaron, en definitiva, las contradicciones, limitaciones y paradojas del Chile de los '80. Aquello condicionó la recepción de su trabajo: mientras para algunos Los Prisioneros fueron la voz de una generación coartada, para otros fueron una expresión del resentimiento social.

En el presente trabajo se examinarán cuatro videoclips del grupo santiaguino: "La voz de los '80" (1984), "Muevan las industrias" (1986), "Maldito sudaca” (1988) y "Corazones rojos" (1990), proponiendo dos amplias dimensiones de análisis: locaciones, lugares y espacios, y lo "audiologovisual" y la performance de los instrumentos. De esta manera, se pretende abordar la intención de este conjunto en recurrir a reconocibles imágenes de la capital (o a segmentos de la población, como las mujeres) y a sonidos que estimulan una evocación, que generan memoria o que se conectan directamente con las letras.

\section{Locaciones, lugares y espacios}

Una dimensión de análisis del videoclip corresponde a las locaciones y sus reminiscencias sociales. Ciertos lugares, monumentos e infraestructuras se 
conectan con sensaciones, emociones y recuerdos que funcionan para diferentes comunidades. Aquello puede relacionarse con una vivencia individual o colectiva, real o imaginada. Un parque, un edificio, un bosque de araucarias o la cordillera se asocian a clases sociales, grupos étnicos o remiten a experiencias de generaciones.

La música popular suele generar vínculos con espacios y memorias (VERNALLIS, 2013). La insinuación a la playa carioca de Ipanema, con una melodía cadenciosa, conecta con una imagen placentera de aquel lugar descrito en "Garota de Ipanema". En contraste, las canciones de rap o hip-hop muestran, en su letra y ritmo, la violencia de algunos sectores de la ciudad. Los dos ejemplos anteriores permiten exteriorizar la ductilidad de las asociaciones entre música y lugares: en algunos casos pueden ser singularizadas (“La joya del Pacífico", para el caso de la ciudad de Valparaíso) y, en otros casos pueden ser relaciones generalizadas ("La ciudad de la furia", de Soda Stereo). En este último caso, podemos recurrir a la noción de ethos urbano propuesta por Adam Krims:

El ethos urbano no es una representación particular, sino una distribución de posibilidades, que siempre tiene límites discernibles y prácticas comunes. No es una imagen de cómo es la vida de cualquier ciudad particular. Se condensan públicamente nociones divulgadas de cómo las ciudades son en general, a pesar de que pueden ser conformadas de manera desproporcionada por el destino de ciertas ciudades particulares (KRIMS, 2007: 7)

Los videoclips también permiten generar o reforzar esta apelación a un ethos urbano a través de los lazos entre música, letra y locaciones, en los cuales se configuran, por ejemplo, los sentidos de pertenencia a un medio urbano mediante el ritmo, las imagénes y los movimientos expuestos en el contexto de una experiencia audiovisual.

Respecto al uso de las imágenes, Illescas advierte que, actualmente, los videos musicales se resisten a denunciar las desigualdades sociales:

Algunos dirán que al público no le gustaría ver cosas 'feas' cuando disfruta de los vídeos, sin embargo, [...] hay vídeos contrahegemónicos con millones de visualizaciones que tratan esos temas que a la burguesía no le gusta que se aludan. 
Es decir, de la parte negativa de su sistema: la pobreza, el hambre, las guerras y todo ese conjunto de cosas tan inoportunas y de 'mal gusto' que, pese a existir de un modo sensacionalista y mistificado en todos los telediarios, no deben aparecer en el flujo del videoclip dominante (ILLESCAS, 2015: 265).

A diferencia de lo manifestado por el autor, Los Prisioneros sí exteriorizaron tales conflictos en sus trabajos audiovisuales, recalcando y reivindicando su procedencia: residentes de San Miguel, una comuna de clase media ubicada en el sector sur de la capital; descendientes de familias con lazos en el proletariado y dependientes de la crisis del sector industrial; identificados como jóvenes excluidos del sistema, sin oportunidades laborales y académicas, quienes anhelan un futuro promisorio al iniciarse la década de los 80 , con participación activa de sus coetáneos para poder romper el statu quo. Aquello se refleja en la "La voz de los ' 80 ", single que abre el casete homónimo de 1984, y cuyo video fue realizado ese mismo año. Mediante una melodía enérgica, este tema anuncia el ocaso de la década pasada, transmitiendo una sensación de optimismo por lo nuevo que se aproxima. El título corresponde a su gancho o hook, que forma parte del estribillo y se repite once veces a lo largo de la canción. Ésta comienza con un fill de batería potente y un ágil riff de guitarra de notas repetidas (con cuatro acordes mayores: Si, Mi, Re y La).

Las primeras estrofas aluden a un movimiento que surgirá en ese período, pero no se sabe cuál es, ni cuándo, irrumpirá. Está llamado a sacudir un ambiente paralizado que exige una transformación. En Deja la inercia de los '70 es la primera vez que se interpela a un "tú". Antes se describía una situación: algo estaba surgiendo en un inicio; luego, retrocedemos al pasado, con los hippies y los punks; y, ahora, se vuelve al presente, dando una orden. No se puede ser un ente inerte, sino que hay que estar preparado para actuar. Todo esto se compone de referencias corporales: abrir los ojos, ponerse de pie, escuchar el latido. Existe un despertar orgánico. Ya viene la fuerza / La voz de los '80 es un anuncio que el hablante advierte, a pesar de que no se sabe cuándo se hará presente. La fuerza no es física; es la voz la que posee potencia. Esto supone que una generación, en los '80, se expresará sin temor. 
En cuanto al videoclip de "La voz de los "80" (dirigido por Yerko Yankovic) podemos señalar que, al comienzo, cuando sólo se escucha la batería, aparecen planos panorámicos de lugares de Santiago: blocks (tal vez de San Miguel), la Torre Entel ${ }^{5}$, la Panamericana ${ }^{6}$, ventiladores en un techo, una calle y, de nuevo, la Torre Entel. Cuando comienzan los acordes de guitarra se aprecia, en un ángulo cenital, la Panamericana con autos y micros de la época. La imagen se extiende hasta que canta Jorge González. Cabe destacar que tal avenida traza una división entre el poniente y el oriente de la capital. En el estribillo (ya viene la fuerza / la voz de los '80), el trío toca sus instrumentos (guitarra eléctrica y un tambor de batería) afuera de una fábrica, con estanques y cañerías.

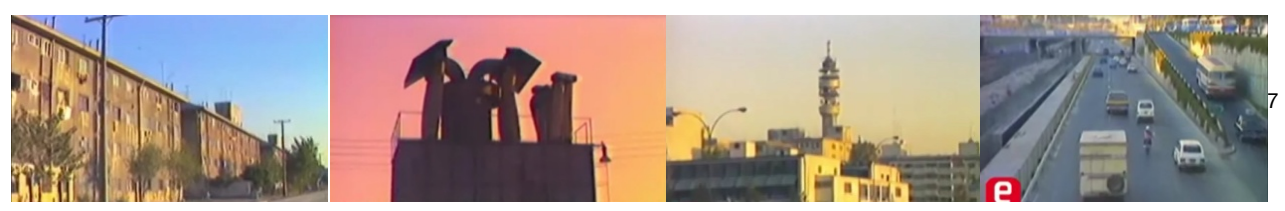

Cuando el vocalista interpreta en los '80 tu rol es estelar, se distingue una imagen de feria libre, con un hombre llevando zapallos en una carreta. En tienes la fuerza, un hombre trota en un parque (como el extenso Forestal) y en eres actor principal, otro saca cebollas. Estas escenas marcan contrastes entre las clases sociales que cohabitan en Santiago de Chile.

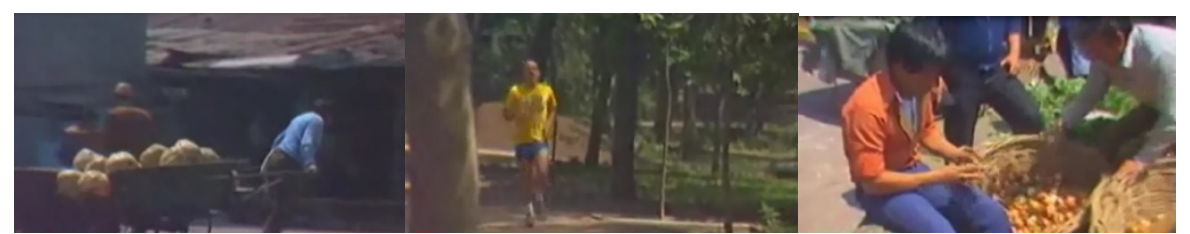

En de las entrañas de nuestras ciudades, surge la piel que vestirá al mundo, se aprecian cañerías y tarros verdes de basura, de ésos que se ocupan en las ferias

\footnotetext{
${ }^{5}$ La Torre Entel, centro de operaciones de la compañía de telecomunicaciones del mismo nombre, se inauguró en 1974, a un año del golpe de Estado en Chile. Ícono arquitectónico del centro de Santiago, con una altura de 127.35 metros, fue el edificio más alto del país hasta 1996.

${ }^{6}$ La Panamericana (conocida comúnmente como Ruta 5) es la autopista más importante de Chile, pues recorre 3.363,97 km. desde el límite con Perú hasta Puerto Montt, ciudad sureña.

${ }^{7}$ Todas las imágenes adjuntas en el texto son capturas de pantalla.
} 
libres.



Desde escucha el murmullo y hasta qué alegría más triste y falsa, González, con micrófono en mano, canta en un sector que podría ser Plaza Italia. Por lo general, esta locación se emplea para fraccionar la ciudad en dos polos simbólicos: el acomodado ("de Plaza Italia para arriba") y el más vulnerable (“de Plaza Italia para abajo"). Luego, aparecen los integrantes con sus instrumentos en el Puente del Arzobispo, que cruza el Río Mapocho (atravesando comunas periféricas, como Pudahuel, Cerro Navia y Quinta Normal).



Hacia el final de este tema, las imágenes corresponden a una calle con edificios antiguos, en color magenta, antenas que remiten a la NASA, alguien escribiendo en un papel, otro limpiando unos tarros de basura y la escena de vehículos transitando por la Panamericana.

Asimismo, en "Muevan las industrias" (dirigido por Daniel de la Vega) las imágenes calzan perfecto con la letra. Como indicó Jorge González a la revista Súper Rock, en 1987, esta pieza "es algo más o menos literal, que intenta mostrar en buena forma lo que es la canción. Las grabaciones las hicimos en una fábrica abandonada del barrio Franklin y en una industria textil en funcionamiento"8. De este modo, en Están paradas esperando a las manos que decidan hacer andar / La neblina las rodea y las oxida y ya piensan en petrificar, se observa un plano panorámico de la fábrica Santiago S.A. (que después se fragmenta en cuatro cuadros), un hombre que mira fijo a la cámara y levanta una caja de tomates,

${ }^{8}$ Súper Rock, 2-23/03/87: 11. 
torres de alta tensión, el interior de una industria y un tractor que pavimenta. En el gancho Las industrias, muevan las industrias / Las industrias, muevan las industrias se repite aquella secuencia.
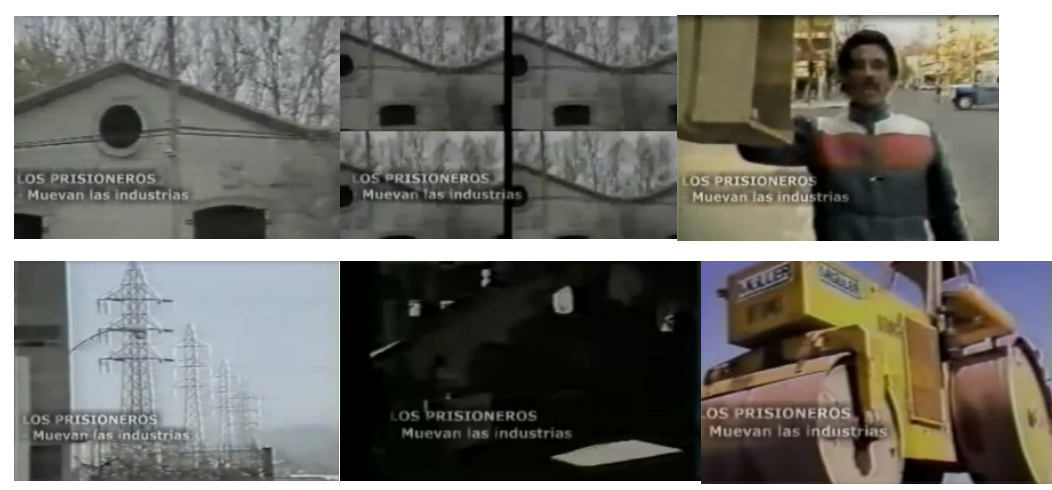

Más adelante, en Las industrias (que no vuelvan más), muevan las industrias González, Narea y Tapia operan maquinarias pesadas, vestidos con overoles azules, mientras se yuxtaponen imágenes de archivo en blanco y negro de fábricas humeando. En el puente del sintetizador se ven un partido de fútbol de barrio, una industria (tal vez una termoeléctrica) y una máquina de producción en serie. En el segundo puente se distinguen unos niños en el techo de una casa modesta, personas haciendo una fila para hablar por teléfono público (al parecer, en el centro de Santiago) y las torres de gas ubicadas en la comuna de Estación Central, emblema de la zona surponiente de la metrópoli.
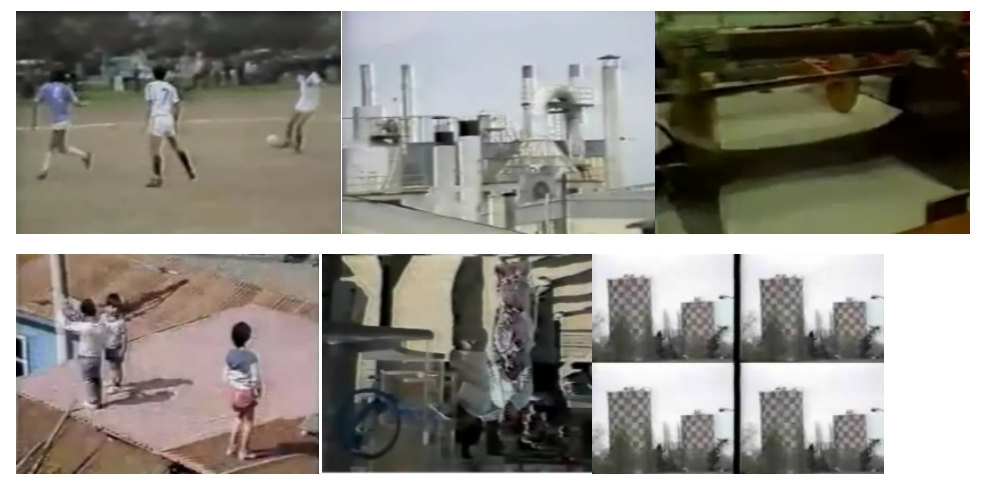

Esta canción, compuesta tras la crisis económica de 1982, revela la incertidumbre de miles de obreros desempleados. Quizás, muchos de ellos se convirtieron en un momento en entes robotizados, tal como plantea la película de 
Charles Chaplin Tiempos modernos. Las imágenes del videoclip refuerzan, entonces, la centralidad del trabajo en la vida urbana y sus dinámicas, como la alienación o la precarización. Este caso no sólo es aplicable a Chile (como reminiscencia histórica de lo ocurrido a inicios de los '80), sino que también a cualquier otra ciudad (semi)industrializada que comparte ese ethos urbano.

Por otro lado, al inicio de "Maldito sudaca" (dirigido por Cristián Galaz) se distingue una calle con una pequeña pared conformada por cubos con la carátula del disco Beatles for sale de The Beatles, un tarro de basura con papel de periódicos (que remite a la canción "La cultura de la basura"), un afiche de la primera etapa de Los Prisioneros pegado en un poste y varias cajas en la vereda.

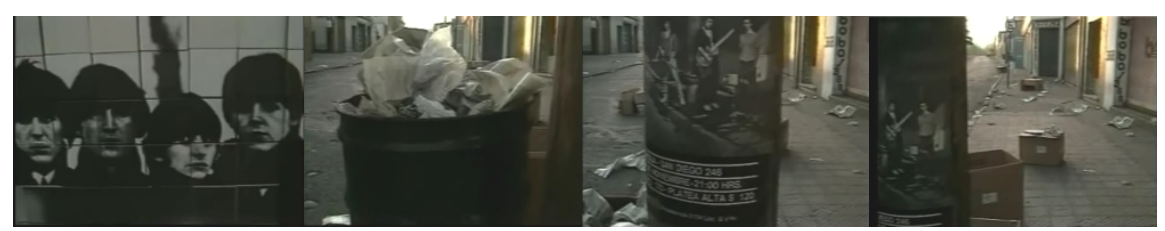

Desde Maldito sudaca, maldito latino y hasta No pongas tus dedos en mi car, González, Narea y Tapia (vestidos de negro, al estilo rockabilly) se sitúan en algunas esquinas de un barrio popular que parece ser Franklin o Patronato y caminan por lugares sucios. Después, se encuentran en un parque de entretenciones. En vil ecuatoriano, cochino latino, vil ecuatoriano y no saludes a mi mujer, la cámara enfoca "de reojo" a un vendedor de algodones de azúcar, quien es moreno y posee rasgos indígenas.

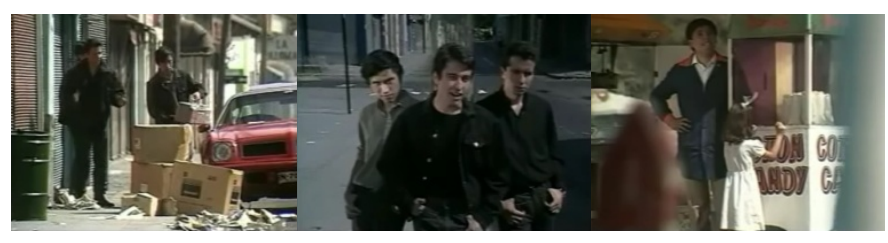

Al final del puente (la la la) la locación cambia: ahora la banda se ubica en una feria libre de Avenida Grecia (sector residencial de clase media). Allí se observan comerciantes, dueñas de casa, jóvenes y niños. Luego que González reventara un tomate con la mano en en mi corazón hay un revólver, los transeúntes saltan al compás de la canción. Entremedio hay otro puente, en el que Narea toca la guitarra en las tres locaciones mencionadas. Después, los integrantes caminan 
por la calle descrita al comienzo, pateando, entre risas, cajas y neumáticos.

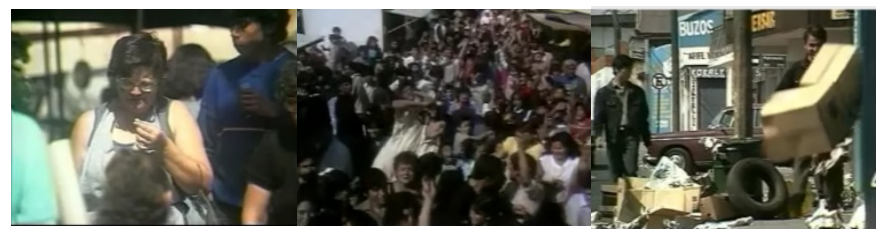

En Maldito sudaca, maldito colombiano / maldito latino, maldito paraguayo, nuevamente la cámara se centra en un hombre moreno. Esa imagen se contradice con la de un ejecutivo de terno y corbata subiendo a su auto rojo, quien se molesta con Los Prisioneros porque colocaron una radio en el capó (esto coincide con maldito sudaca, maldito latino).

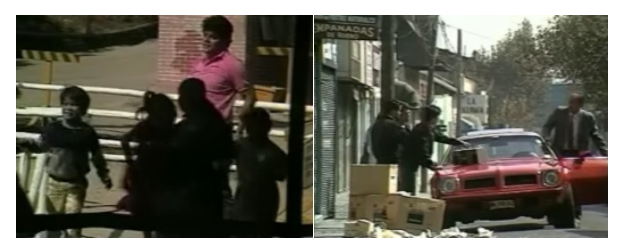

Este videoclip, que refuerza la idea de la discriminación racial y cultural, muestra la segregación social que parece pertenecer al ethos urbano, tal como la industrialización y la alienación.

En los videoclips de Los Prisioneros, los planos panorámicos son esenciales para que la audiencia (santiaguina, sobre todo) se ubique en ciertas locaciones. Esto se demuestra en "La voz de los '80", "Muevan las industrias" y "Maldito sudaca". Por otro lado, el trío sanmiguelino adopta el plano detalle y el primerísimo primer plano en algunas escenas de "Maldito sudaca" y "Corazones rojos" (dirigido por Cristián Galaz), para enfatizar, a través de la imagen, ideas plasmadas en las letras. En el primer ejemplo, el plano detalle cobra relevancia cuando en mi corazón hay un revólver González manifiesta su ira, reventando un tomate con la mano. En ese videoclip se observa un primerísimo primer plano al final, cuando el líder exclama iplaneta-eta-eta-eta-eta! (un loop). Cabe destacar

\footnotetext{
${ }^{9}$ Vernallis explica que, en los ' 80 , se solía dividir la imagen en cuadrantes o bloques. "Hoy es un efecto familiar, pero en los '80 era algo tremendamente emocionante” (VERNALLIS, 2013: 213). Esa técnica se puede apreciar en la introducción del videoclip "Muevan las industrias".
} 
que, luego de ese grito, la cámara cambia de dirección y enfoca una rueda de la fortuna de un parque de entretenciones, mientras que en la coda suena la melodía del famoso vals "Si vas para Chile" (uno de sus versos dice $Y$ verás cómo quieren en Chile / al amigo cuando es forastero; esto claramente se contrapone al racismo expuesto en "Maldito sudaca").

En tanto, el primerísimo primer plano también se aprecia en "La voz de los '80", cuando Jorge canta saturada de aburrimiento, y en "Corazones rojos", en porque yo soy un hombre y no te puedo mirar. Ésta es la única canción del casete Corazones (1990) que aborda explícitamente una temática social: el machismo imperante en la realidad chilena, que se traduce en desigualdad de estatus y de oportunidades para la mujer. El hablante, situado como un hombre que legitima el patriarcado, le recuerda a la mujer su rol, que siempre está supeditado al hombre.

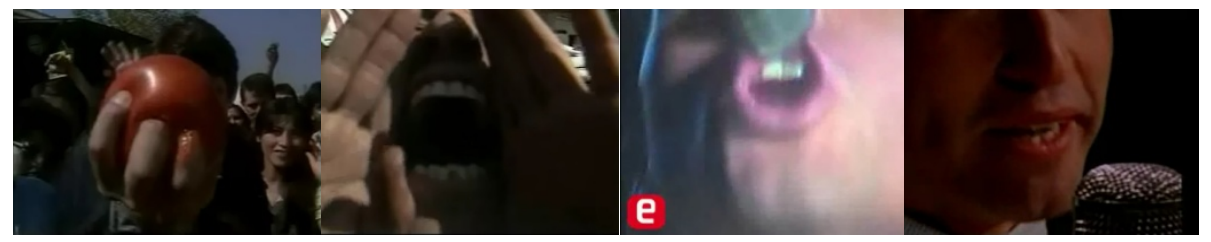

Ejemplos de plano detalle y primerísimo primer plano en "Maldito sudaca", "La voz de los '80" y "Corazones rojos"

En "Corazones rojos" los ángulos de cámara son importantes, precisamente por cómo se expresa la imagen de la mujer subordinada que intenta liberarse del yugo masculino. Eso se materializa en el estribillo (jHey, mujeres!), donde unos niños escolares le gritan a una mujer vestida de negro y cubierta con un velo blanco - antes encarnada en una maniquí-, que está arriba de un cubo rosado (ángulo contrapicado). Ésta es una invitación para que las mujeres se levanten y reaccionen. Por eso, la frase se entona con energía.

\section{Lo "audiologovisual" y la performance de los instrumentos}

Chion propone la instauración del término "audiologovisual", puesto que en el cine el lenguaje cumple un rol preponderante, sea escrito (subtítulos, generadores de contenido) u oral (diálogos, intervenciones vocales). De esta forma, se podría "determinar, regular y justificar la estructura del conjunto" (CHION, 1999: 283). 
Como agrega el autor, los sonidos en una pieza audiovisual pueden acopiarse unos sobre otros y "son libres de cualquier ley realista: música, voces en off, diálogos, ruidos ambientales realistas, etc., se pueden mezclar en un filme" (CHION, 1999: 280). Vale decir, es posible oír (de forma conjunta o por separado) distintas señales sonoras o signals (sonidos esporádicos), tal como definió Schafer en 1977.

En tanto, González recalca que, junto a la imagen y la locución, la música conforma un universo significante. Esto lo denominó heterosemiosis, cuyo "sentido textual viene definido como la resultante de una relación dialéctica establecida en la suma y la interacción de 'efectos' de sentido esencialmente diversos" (GONZÁLEZ, 1999: 71).

En el caso de Los Prisioneros, el texto escrito aparece por primera vez en "Muevan las industrias". En una secuencia (desde el 3'17 y hasta el 3'28) se observa la frase las industrias (dividida en cuatro sílabas) cuando la banda toca sus instrumentos modernos. Después, cuando unos obreros operan una maquinaria pesada, se distingue muevan las industrias al lado inferior derecho del encuadre. Además de contar con la voz de González, el texto sirve para potenciar el estribillo.

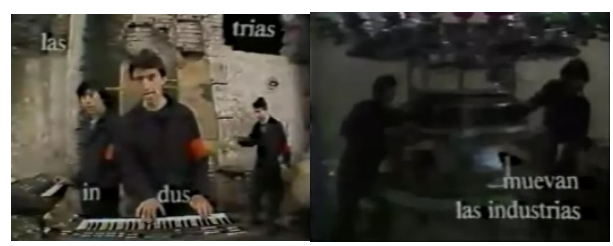

En cuanto a lo oral, en "Corazones rojos" se escuchan a unos escolares que le gritan a una mujer-maniquí. Así, se superponen las voces de los niños interpretando ¡Hey, mujeres!, la versión original del disco y la imagen de una fémina que, al ser interpelada por unos infantes, realiza una performance con la bandera de Texas ${ }^{10}$ arriba de un cubo. Todo eso contiene una información

\footnotetext{
${ }^{10}$ No es casual que dicha mujer-maniquí esté cubierta por la bandera de Texas. Además del enorme parecido con el emblema chileno, probablemente, el director del videoclip intentó vincular el machismo imperante en tierras australes y el conservadurismo exacerbado de aquel estado norteamericano.
} 
semántica.

En los videos de esta banda, las señales sonoras resaltan las ideas reflejadas en las imágenes. Esto se puede advertir en los primeros veinte segundos de "Maldito sudaca". En la secuencia inicial - donde la cámara enfoca una pequeña muralla de cubos con una fotografía de The Beatles, unos tarros de basura repletos, un afiche de Los Prisioneros pegado en un poste y una vereda con cajas de cartón- parece que alguien sintoniza varias estaciones radiales: se escucha "A hard day's night", ladridos probablemente sampleados (que remiten a "El baile de los que sobran"), la voz de Sergio Campos, histórico locutor de Radio Cooperativa (medio de comunicación opositor a la dictadura); un tango, la introducción de "La cultura de la basura" (el sonido de alguien hojeando un libreto radial: $Y$ tenemos aquí un disquito simpático para ti, muñeca, que estás solita en tu casa. A ver, a ver... Ah, Los Prisioneros: "La cultura de la basura" ${ }^{11}$ ) y, por último, la frase escuchando radio, correspondiente a esa canción. Estos elementos podrían ser catalogados de extradiegéticos, aunque también corresponderían a lo que Murray Schafer denominó como "esquizofonía":

El régimen de disociación entre espacio y sonido que los aparatos mediáticos operan genera una especie de desterritorialización que puede llevar a un estado caótico y angustiante, y a un cierto aprisionamiento auditivo. Eso se daría en virtud de un ambiente que propicia la sensación de descontrol de la audición, próximo a la agonía de sentir el ego desfragmentando debido a la invocación generada por los dispositivos sonoros (OBICl, 2008: 48).

Otro ejemplo de sonidos que se vinculan con las imágenes es "Muevan las industrias". Este tema contiene sonidos "industriales" cuyos timbres son reconocibles (golpes sampleados de balones de gas) y que, en el videoclip, se expresan a través de mazazos de Tapia a un tubo de alcantarillado y a un tarro de

\footnotetext{
${ }^{11}$ Allí Los Prisioneros ironizan con ser parte de la cultura de masas a la cual critican. Si bien en ese tema se identifican con un "nosotros", en el que también participan, en realidad, plantean un cuestionamiento desde adentro a este mundo superficial, autómata, de la música de la radio, del estadio, de las historietas y de la TV.
} 
basura. "Muevan las industrias" está notoriamente inspirado en "People are people" de Depeche Mode: mientras en el primero las acciones se desarrollan en una fábrica, en el segundo se ejecutan desde un submarino. En ambos casos, los sonidos "metálicos" provienen de martillazos a una cadena o de la operación de maquinaria pesada.

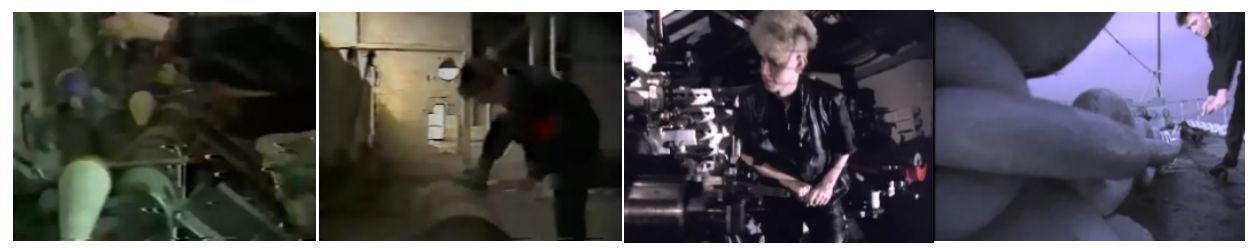

"Muevan las industrias" (1986) versus "People are people" (1984)

El sintetizador, la fuente emisora de aquellos sonidos de fábrica, deja, aquí, de ser un objeto acusmático y se convierte en "protagonista" del videoclip: si la melodía se escucha, observamos de dónde proviene.

Young (2013) afirma que el sintetizador simbolizó la identidad del new wave, transformándose en lema central de la modernidad. Por tal razón, este instrumento fue esencial en vídeos de artistas como Depeche Mode ("Just can't get enough"), Yazoo (“Don't go"), Gary Numan (“Cars”) y Devo (“Time out for fun”). En estos casos, los músicos se mueven inexpresivamente por el espacio de forma robótica. Vernallis asegura que "a veces, los músicos de los '80 parecían como si les hubieran dado un tranquilizante de elefante [...] Tal conducta como de maniquí puede haber sido porque los artistas aún no comprendían el lenguaje del video musical" (VERNALLIS, 2013: 221).

Por otro lado, Gabrielli se refiere a la "performance de los instrumentos musicales" (GABRIELLI, 2010: 100), concepto atribuido al director francés Michel Gondry. La autora señala que el realizador - que ha trabajado con Daft Punk, The Chemical Brothers, Björk y Paul McCartney, entre otros - se destaca por:

Llamar la atención del espectador con un solo grupo de elementos de la composición visual. La escenografía se basa en la estructura simétrica formada por la composición de diferentes elementos: mientras la cámara está filmando de frente un conjunto, el espectador ve a los personajes/instrumentos ocupando totalmente la pantalla (GABRIELLI, 2010: 102). 
Retornando a los videoclips de Los Prisioneros, en "Muevan las industrias" el sintetizador cobra relevancia en el estribillo (las industrias, muevan las industrias) y en los versos voy a llegar a la gran máquina y si agacho un poco la cabeza. En el coro aparecen González, Narea y Tapia con overoles azules ${ }^{12}$ y tocando -casi inmóviles - sus modernos sintetizadores Casio modelo CZ y la batería electrónica Simmons SDS-9. Después, en el puente (del 1'56 al 2'12), el sintetizador se encuentra en un primer plano, aunque se intercalan otras imágenes: fábricas, un partido de fútbol de barrio y una máquina de producción en serie.

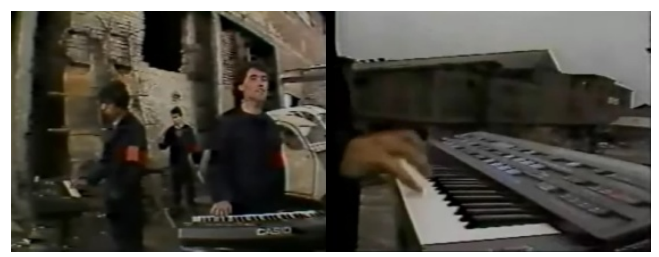

Así, el grupo ostenta su nuevo equipamiento (obtenido tras la firma con el sello EMI), a diferencia de la precariedad de "La voz de los '80", donde sólo se exhiben una guitarra eléctrica y un tambor de batería parchado.

\section{Conclusiones}

Las canciones pop, generalmente, son consideradas como "vehículos de reminiscencia" (VAN DIJCK, 2009). El autor sostiene que la música pop grabada también podría generar "un marco cognitivo a través del cual los significados construidos en conjunto se transponen a la memoria individual, resultando en un mezcla intrincada de recuerdo e imaginación, de recuerdos entremezclados con extrapolaciones y mitos" (VAN DIJCK, 2009: 110).

Mediante la fusión de sonidos, música, letra e imágenes, el videoclip posibilita

${ }^{12}$ Un artista que enfatizó la relación entre lugar, comunidad e identidad fue el estadounidense Bruce Springsteen, quien ha profundizado en las problemáticas de la clase proletaria. Por eso, para sugerir compromiso, luce "atuendos de trabajo", como blue jeans y camisetas blancas (Connell y Gibson 2001). En el caso de "Muevan las industrias", Los Prisioneros aluden a la clase obrera vistiendo overoles azules, que remiten, por ejemplo, a trabajadores de industrias textiles. 
un "diálogo emocional" (VERNALLIS, 2013) entre artistas y audiencias. Por eso, no es de extrañar que en una secuencia la cámara registre locaciones, rostros $u$ objetos para aludir a clases sociales, grupos etarios o minorías sexuales. Como ilustra Chion, las imágenes sólo se comprenden debido a su contigüidad. De esa forma, "la memoria del espectador funciona entonces como un mezclador ideal, muy superior a una máquina, de impresiones visuales encadenadas unas a otras en el tiempo" (CHION, 1993: 129).

Este trabajo ha sido una aproximación a los videoclips de Los Prisioneros, considerando ciertas categorías de análisis. Aquí hemos atestiguado cómo sus obras audiovisuales - cargadas de simbolismos locales- permiten que el espectador rememore, se identifique con un colectivo y asocie con generaciones, lugares y acontecimientos. Aquello se acentúa con el empleo de planos y ángulos de cámara y sonidos sugestivos, y con una performance atrayente. Estos elementos potencian las sensaciones evocadas por la melodía de las canciones y generan en el espectador una constante estimulación, lo que se constata en "La voz de los '80" (abre los ojos, ponte de pie / escucha el latido, sintoniza el sonido / agudiza tus sentidos).

En cuanto a las limitaciones de este estudio, cabe señalar que no se ha abordado el concepto de performance desde la interacción de los personajes en el encuadre; más bien, nos hemos abocado a la preponderancia del instrumento musical y su relación con la canción. Por otro lado, sería interesante ahondar en cómo el videoclip funciona como una narrativa audiovisual, en su vertiente clásica (una historia) o en su versión post-clásica (una composición menos lineal).

\section{Bibliografía}

AUFDERHEIDE, Patricia. "Music Videos: The Look of the Sound". Journal of Communication, 36, 1, 1986, 57-78.

CHION, Michel. El sonido: Música, cine, literatura. Barcelona: Paidós Ibérica, 1999.

CHION, Michel. La audiovisión: Introducción a un análisis conjunto de la imagen y el sonido. Barcelona: Paidós Ibérica, 1993. 
CONNELL, John; GIBSON, Chris. Sound tracks: Popular music, identity and place. Londres y Nueva York: Routledge, 2001.

CONTARDO, Óscar; GARCÍA, Macarena. La era ochentera: Tevé, pop y under en el Chile de los ochenta. Santiago de Chile: Ediciones B, 2005.

GABRIELLI, Giulia. "An Analysis of the Relation between Music and Image. The Contribution of Michel Gondry". In: KEAZOR, Henry; WÜBBENA, Thorsten (eds.). Rewind, Play, Fast Forward: The Past, Present and Future of the Music Video. Londres: Transaction Publishers, 2010. 89-110.

GARCíA, Marisol. Canción Valiente: 1960-1989, tres décadas de canto social y político en Chile. Santiago de Chile: Ediciones B, 2013.

GONZÁLEZ, Juan Miguel. El sentido en la obra musical y literaria: Aproximación semiótica. Murcia: Universidad de Murcia, 1999.

ILLESCAS, Jon. La dictadura del videoclip: Industria musical y sueños prefabricados. Barcelona: El Viejo Topo, 2015.

KRIMS, Adam. Music and Urban Geography. Londres y Nueva York: Routledge, 2007.

LIÑERO, Germán. Apuntes para una historia del video en Chile. Santiago de Chile: Ocho Libros Editores, 2010.

OBICI, Giuliano. Condição da escuta. Mídias e territórios sonoros. Río de Janeiro: 7 Letras, 2008.

OSORIO, Javier. "La bicicleta, el Canto Nuevo y las tramas musicales de la disidencia: Música popular, juventud y política en Chile durante la dictadura, 19761984". A Contracorriente, 8, 3, 2011, 255-286.

VAN DIJCK, Jose. "Remembering Songs through Telling Stories: Pop Music as a Resource for Memory". In: BIJSTERVELD, Karin; VAN DIJCK, Jose (eds.). Sound Souvenirs. Audio Technologies, Memory and Cultural Practices. Amsterdam: Amsterdam University Press, 2009. 107-119.

VERNALLIS, Carol. Unruly Media. YouTube, Music Video, and the New Digital Cinema. Nueva York: Oxford University Press, 2013.

VILCHES, Patricia. "De Violeta Parra a Víctor Jara y Los Prisioneros: Recuperación de la memoria colectiva e identidad cultural a través de la música comprometida". Revista de Música Latinoamericana, 25, 2, 2004, 195-215. 


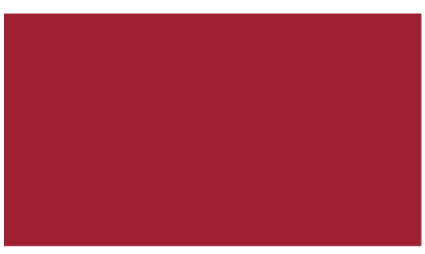

rebeca

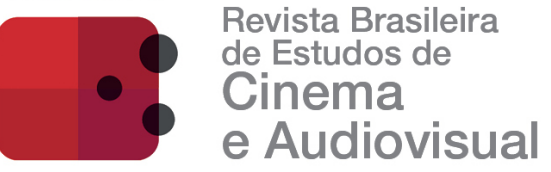

YOUNG, Jon. "Roll Over Guitar Heroes, Synthesizers Are Here". In: CATEFORIS, Theo (ed.). The Rock History Reader. Londres y Nueva York: Routledge, 2013. 151-181. 